\title{
THICKNESS MEASUREMENT OF THIN OIL LAYERS IN TRIBOELECTRICAL PHENOMENON ASPECT
}

\author{
POMIAR GRUBOŚCI CIENKICH WARSTW \\ OLEJOWYCH W ASPEKCIE WYSTECPOWANIA \\ ZJAWISKA TRIBOELEKTRYCZNEGO
}

\section{Emil Nowiński, Bolesław Giemza, Marek Domański}

Instytut Techniczny Wojsk Lotniczych

boleslaw.giemza@itwl.pl,emil.nowinski@itwl.pl,marek.domanski@itwl.pl

\begin{abstract}
This paper presents problems of oil film thickness measurements, especially during tribological experiments. There are many methods of oil layer measurement. More of them is used in measurement apparatus. Most popular method to oil film thickness is electric method. Authors indicate that triboelectrical phenomenon disrupts the real value of resistance because of charge particles which change conductance of the oil layer.
\end{abstract}

Keywords: oil film thickness, oil conductance, triboelectric phenomenon.

Streszczenie: Tematem publikacji sa problemy oceny grubości filmu olejowego $w$ węzłach tarcia. Literatura przedstawia wiele metod takich pomiarów. Najbardziej popularna, wykorzystywana także $w$ aparatach laboratoryjnych jest metoda rezystancyjna, która polega na odnoszeniu rezystancji warstwy do jej grubości. Autorzy wskazuja na błędne zatożenia tej metody ze względu na tworzenie ładunków elektrycznych w strefie tarcia, co zmienia przewodność takiej warstwy.

Stowa kluczowe: grubość filmu olejowego, przewodność oleju, zjawisko triboelektryczne 


\section{Wprowadzenie}

Wykonywanie pracy mechanicznej przez jakąkolwiek maszynę związane jest z pokonywaniem oporów tarcia. Opory te uzależnione są od wielu czynników, m.in. takich jak wielkość obciążenia, cechy konstrukcyjnych węzła tarcia, rodzaj materiałów z których zbudowane są elementy trące, chropowatość powierzchni, rodzaju smarowania i inne. Na wielkość siły tarcia ma także wpływ grubość warstwy smarowej rozdzielającej powierzchnie trące. Zależność oporów tarcia od grubości filmu olejowego przybliża krzywa przedstawiona na rys.1

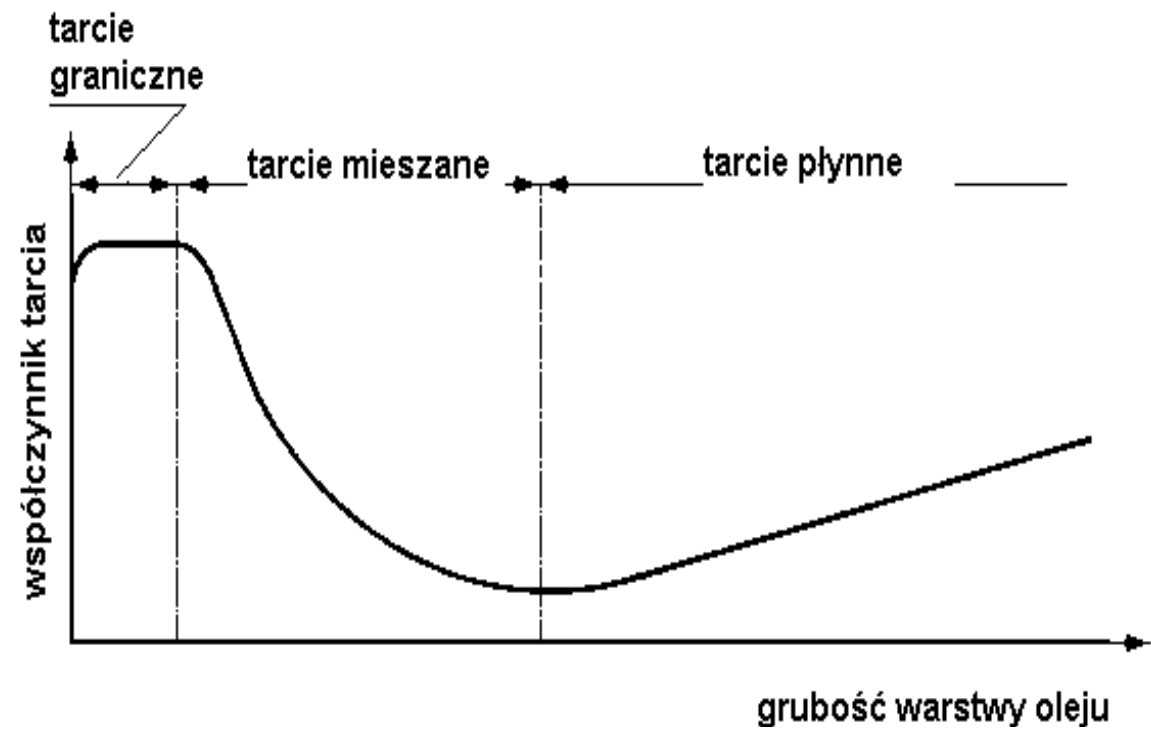

Rys. 1. Zależność wspótczynnika tarcia od grubości warstwy oleju dla różnych rodzajów tarcia [17].

Z powyższej zależności wynika, że najniższe opory ruchu występują przy minimalnej grubości warstwy oleju, znajdującego się pomiędzy trącymi elementami. Jest to bardzo ważna informacja, wskazująca na konieczność stosowania jak najcieńszych filmów olejowych przy zachowaniu tarcia płynnego. Jednak nie zawsze możliwe jest stworzenie takich warunków, w których warstwa smarująca całkowicie rozdzielać będzie powierzchnie trące. Tym bardziej należy mieć świadomość, że podczas tarcia granicznego i mieszanego występują zjawiska triboelektryczne, które jak się okazuje mają wpływ nie tylko na grubość warstwy olejowej, ale także na niepewność pomiaru tejże warstwy. Dlatego też, przy ocenie grubości filmu olejowego powinno się uwzględniać także powstawanie w strefie tarcia ładunków elektrycznych. 


\section{Metody oceny grubości warstwy smarowej}

Obecnie, do najprostszych i najszybszych metod oceny grubości warstw smarowych należą metody matematyczne. Literatura $[1,2,17,18]$ przedstawia wiele modeli matematycznych opisujących zmiany grubości filmu olejowego.

Pierwsze próby oszacowania grubości filmu olejowego pomiędzy zębami przekładni zębatej były podjęte przez Martina w 1926 r. [19]. Przypuszczał on, że minimalna grubość filmu olejowego mieści się w zakresie wielkości atomu. Kilka lat później Artel określił grubość filmu na poziomie wysokości chropowatości.

McKee i Stanton obliczyli grubość warstewki oleju w małym łożysku na poziomie $1,37 \mu \mathrm{m}$, ale zastrzegli z kolei, że grubość takiego filmu w większych łożyskach może wynosić nawet $2,54 \mu \mathrm{m}$.

Do obliczeń grubości warstewki smarowej wykorzystywane jest głównie równanie Reynoldsa oraz parametry chropowatości powierzchni. Fuller z kolei uzależnia grubość warstwy smarującej od luzu poprzecznego w łożysku ślizgowym i wielkości samego łożyska wskazując, że im większy jest luz pomiędzy czopem wału, a łożyskiem oraz im większy promień łożyska, tym wzrasta grubość filmu olejowego[1,20].

Jednym z bardziej popularnych modeli obliczeniowych jest wzór Dowsona i Higginsona [1]. Przyjmuje on następującą postać:

$$
\frac{h_{\min }}{R}=2,65 \frac{U^{0,7} G^{0,54}}{W^{0,13}}
$$

$\mathrm{Na}$ przykładzie powyższej zależności widać, że grubość filmu olejowego $\mathrm{w}$ węźle tarcia związana jest $\mathrm{z}$ wielkościami charakteryzującymi materiały (zastępczy moduł Younga, lepkość cieczy) oraz parametrami wymuszeń, takimi jak obciążenie i prędkość ślizgania. W równaniu Dowsona-Higginsona, grubość warstwy smarowej określona jest jako minimalna, więc należy się spodziewać, że wartości rzeczywiste mogą być większe od obliczonych.

Oprócz metod analitycznych, stosowanych jest także kilka technik pomiaru grubości warstwy olejowej i mogą być one zaszeregowane do metod: elektrycznych, optycznych i akustycznych.

Wśród elektrycznych można wyróżnić metodę rezystancyjną, pojemnościową i pojemnościowo - rezystancyjną. Najczęściej stosowaną i najprostszą jest metoda rezystancyjna, polegająca na pomiarze oporu elektrycznego pomiędzy dwiema powierzchniami rozdzielonymi substancją smarową. Otrzymana wartość rezystancji przedstawiana jest jako grubość filmu olejowego zgodnie z przyjmowaną liniową zależnością grubości warstwy od oporu elektrycznego. Sposób takiego pomiaru z wykorzystaniem zjawiska spadku napięcia na rezystorze, przedstawia rysunek $\mathrm{nr} 2$. 


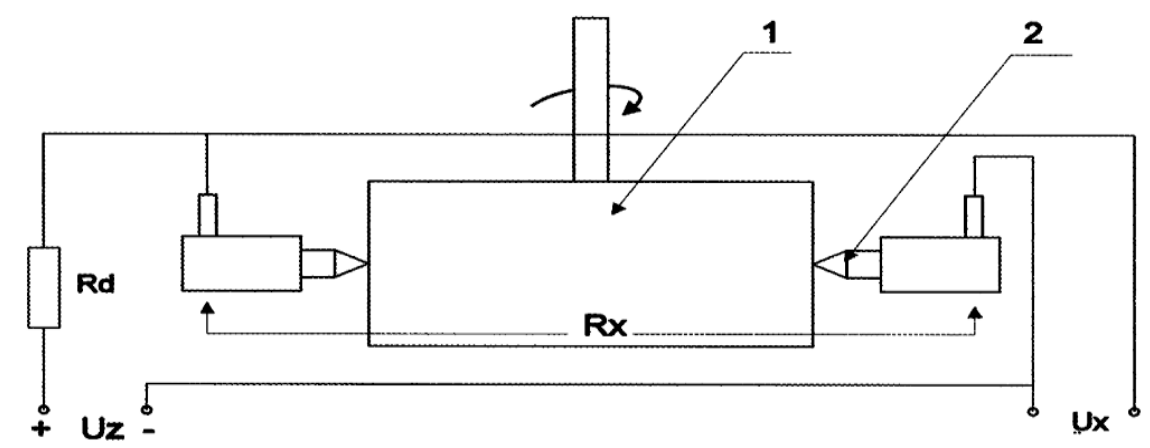

Rys.2. Schemat pomiaru rezystancji w ruchu obrotowym; 1 - próbka obrotowa, 2 - przeciwpróbka.

Natomiast wartość rezystancji Rx oblicza się z wzoru przedstawionego poniżej:

$$
R_{f}=\frac{R_{d} \cdot U_{x}}{U_{z}-U_{x}}
$$

Pierwsze próby wykorzystania metody elektrycznej do oceny grubości warstwy smarowej miały miejsce w 1946 r. i polegały na pomiarze rezystancji pomiędzy tuleją cylindrową i pierścieniem tłokowym w silniku. Metoda ta stosowana jest dość powszechnie do pomiaru grubości filmu olejowego (również w aparatach laboratoryjnych) pomimo, iż wskazuje się na jej pewne niedoskonałości [23]. Wady tej metody polegają na występowaniu dodatkowych zakłóceń $\mathrm{w}$ postaci zanieczyszczeń i produktów zużycia oraz występowaniu „przebić” prądu elektrycznego. Informacja dotycząca wyładowań w strefie tarcia może mieć nie tylko związek z prowadzeniem eksperymentów z użyciem elektrycznych metod pomiarowych, ale także $\mathrm{z}$ występowaniem zjawiska triboelektrycznego, które występuje z mniejszym lub większym nasileniem w zależności od warunków tarcia i materiałów zastosowanych jako para cierna.

Dlatego też, wyniki pomiarów obarczone są często dużą niepewnością, co niekiedy zupełnie ogranicza możliwość stosowania tej metody oceny [22].

Ze względu na ciągłe dążenia dotyczące poprawy sprawności urządzeń oraz rosnące wymagania redukcji emisji spalin w silnikach spalinowych, bardzo ważnym aspektem jest optymalizacja grubości filmu olejowego na powierzchniach pary trącej tłok - cylinder. Badania polegające na ocenie filmu olejowego na ściance cylindra silnika podjęli Tamminen, Sandström i Sherington [16] stosując także metodę elektryczną, ale wykorzystując w tym celu czujniki pojemnościowe. Ze względu na zastosowanie sensorów o różnych charakterystykach, nie było możliwe bezwzględne określenie grubości filmu olejowego. Najmniejsza wartość, jaką zdołano zarejestrować oscylowała w granicach $1 \mu \mathrm{m}$. Na podstawie badań stwierdzono, że im większe było obciążenie silnika tym grubość warstwy smarowej znajdującej się 
pomiędzy tłokiem a cylindrem rosła. Zakres mierzonych wartości grubości filmu olejowego w punktach pomiarowych zawierał się w granicach 1-20 $\mu \mathrm{m}$.

Pojemnościową metodę pomiaru grubości filmu olejowego stosował także Irani w korbowodach silników spalinowych. Mierzone wartości grubości oscylowały w zakresie 5 - $40 \mu \mathrm{m}$. Z kolei [19] wyniki grubości warstwy smarowej, jakie otrzymywali na czopie korbowodu Glavatski, Uusitalo i Spoin, mieściły się w zakresie 60 - $100 \mu \mathrm{m}$ w zależności od zmian prędkości i obciążenia układu.

Porównując literaturowe wartości grubości warstwy olejowej między czopem wału korbowego, a łożyskiem korbowodu, które uzyskano w różnych eksperymentach prowadzonych tą samą metodą pomiarową, należy stwierdzić, że otrzymane wyniki są bardzo rozbieżne. Na ich podstawie nie można wnioskować o minimalnej, czy nawet średniej grubości filmu olejowego pomiędzy czopem wału korbowego silnika, a korbowodem. Twierdzi się nawet [22], że pojemnościowa metoda pomiaru grubości nie powinna być stosowana do oceny bardzo cienkich warstw. Według Zang Peng i Wen-jie [18] metoda pojemnościowa może być użyta jedynie podczas smarowania hydrodynamicznego. $\mathrm{W}$ przypadku smarowania mieszanego, metaliczne cząstki stałe oraz kontakt metaliczny powierzchni trących mogą wpłynąć na uzyskanie błędnych wyników. Z kolei metoda rezystancyjna może być użyta $\mathrm{w}$ zakresie smarowania elastohydrodynamicznego, jednakże za pomocą tej metody nie można jednoznacznie określić grubości filmu [18].

Do nowszych i dynamicznie rozwijających się metod pomiaru grubości filmu olejowego wykorzystywane są techniki optyczne. Ze względu na wysoką dokładność są one coraz szerzej wykorzystywane. Już w 1967 r. Cameron i Goher użyli optycznego interferometru do pomiaru elastohydrodynamicznego filmu olejowego, a idea tego pomiaru pokazana została na rys.3. [21].

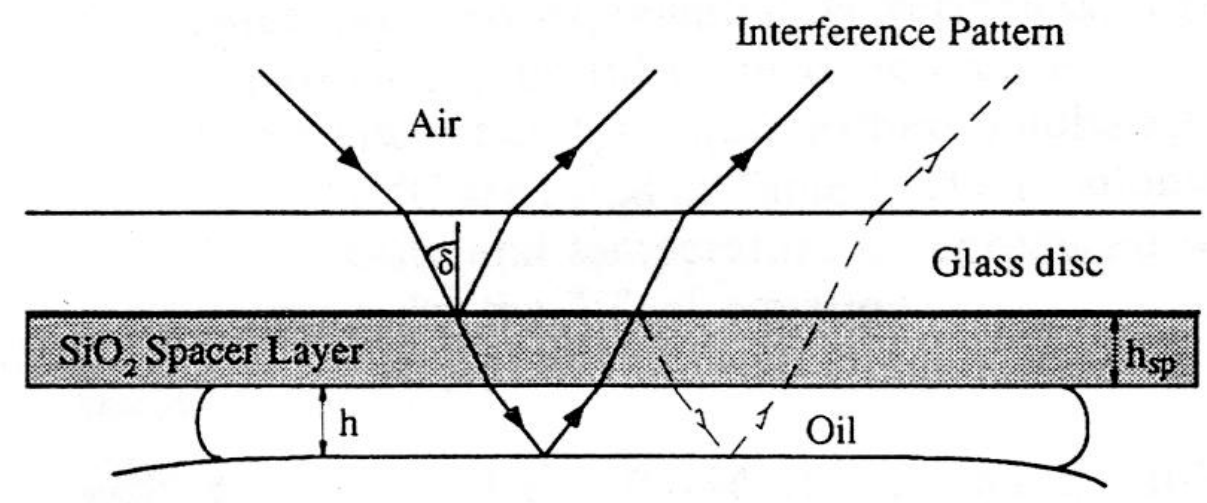

Steel Ball

Rys. 3. Idea pomiaru optycznego grubości warstwy olejowej. 
Metoda ta umożliwia ocenę grubości w zakresie 1-100 nm, a więc odpowiadającym wymiarom poprzecznym bardzo cienkich warstw smarowych. Jednak i tutaj wyniki mogą być obarczone poważnym błędem wynikającym chociażby z kilkukrotnego załamania wiązki światła w przypadku istnienia kilku różnych warstw filmu olejowego. Także przyjęcie niewłaściwego indeksu refrakcyjnego może skutkować około $10 \%$ niepewnością wyniku [18].

Analizując cechy węzła tarcia w interferometrach optycznych należy się spodziewać, że z uwagi na różną energię powierzchni pary trącej (szafiru i metalu), ich inną chropowatość i stopień zwilżalności dla analizowanych materiałów, grubość filmu smarowego rozdzielającego szafirowy dysk i metalową próbkę będzie inna, aniżeli dla pary ciernej wykonanej z tego samego materiału. Podobne spostrzeżenia prezentują Peng i Wen-jie twierdząc, że metody optyczne i optoelektroniczne pomiaru grubości warstw smarnych nie odzwierciedlają zjawisk zachodzących podczas pracy (tarcia) elementów maszyn, gdyż $\mathrm{w}$ badawczych metodach optycznych jedno z ciał trących musi być przezroczyste (wykonane ze szkła).

W innej próbie określenia zjawisk zachodzących podczas tarcia [18] Martin i Grossiord obserwowali grubość filmu olejowego przy użyciu mikroskopu skaningowego o dokładności pomiaru $0,5 \mathrm{~nm}$. Utworzony wielowarstwowy film smarny pomiędzy stalowymi powierzchniami trącymi nie przekraczał grubości 100nm. Jednakże ze względu na występowanie „zakłóceń” m.in. w postaci chropowatości powierzchni, bardzo trudno o dokładnie określić zmiany grubości warstewki smarującej. Również Luo, Wen i Huang [18] na podstawie badań i własnych obserwacji stwierdzili, że metody optoelektroniczne sprawdzają się jedynie do obserwacji powierzchni po badaniach tribologicznych i nie są odpowiednimi narzędziami do badań zjawisk w strefie tarcia.

Przedstawione ograniczenia są podstawą do dalszych poszukiwań metod badawczych pozwalających w większym zakresie określać grubość warstw substancji smarowych.

Kolejną z metod pomiarowych wykorzystywanych do oceny grubości warstw smarowych jest metoda ultradźwiękowa. Polega ona na przyłożeniu do jednej z powierzchni trących źródła drgań o wysokiej częstotliwości (powyżej 20kHz) i ocenie czasu powrotu fali dźwiękowej, odbitej od powierzchni dwóch elementów trących. W praktyce, sygnały przekazywane są do czujników za pomocą elementów sprężystych bądź też poprzez zanurzenie czujnika ultradźwiękowego w cieczy, mającej bezpośrednią styczność z elementem przenoszącym drgania. Metody te stosowane były przez Reddyhoff'a i Dwyer Joyce'a do oceny filmu smarowego w łożyskach, co przedstawia rysunek 4. 
Autorzy uzyskują wyniki grubości filmu olejowego w zakresie $4-20 \mu \mathrm{m}$, ale wskazują przy tym, że dokonywane pomiary powinny być przeprowadzane w zakresie tarcia hydrodynamicznego [21].

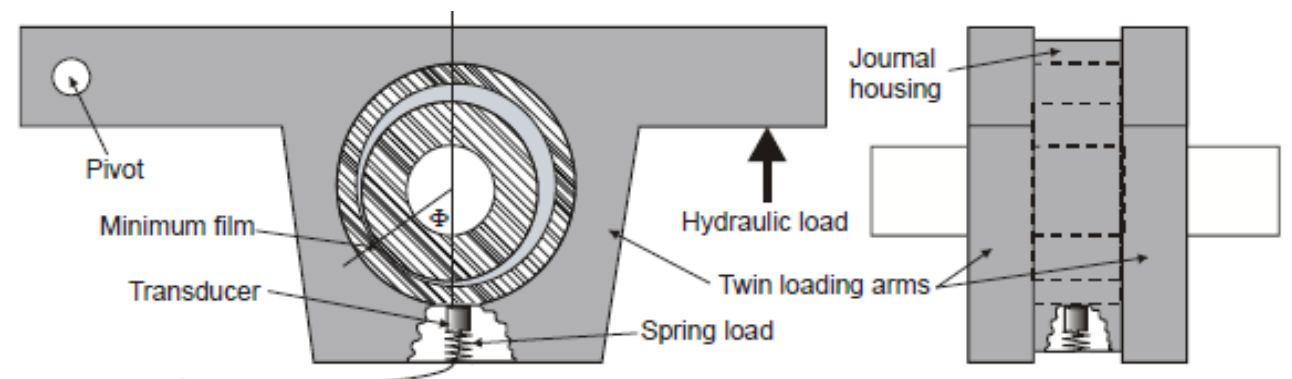

Rys. 4. Ultradźwiękowa metoda pomiaru grubości filmu olejowego w tożysku ślizgowym [21].

Na podstawie przeglądu literatury można śmiało potwierdzić, że problem pomiaru grubości filmu olejowego istnieje nadal i bardzo trudno jest znaleźć odpowiednią metodę do jego pomiaru. Dodatkową trudnością przy doborze odpowiedniej metody pomiarowej do oceny grubości warstwy smarowej jest fakt występowania zjawiska triboelektrycznego, które może przyczyniać się do otrzymywania błędnych wyników.

\section{Zjawisko triboelektryczne i pomiar grubości warstwy smarowej}

Zjawisko triboelektryczne to najprościej mówiąc powstawanie ładunków elektrycznych w węźle tarcia, podczas tarcia suchego, granicznego i mieszanego, ale także jak wskazuje na to literatura podczas tarcia płynnego. Zakres występowania ładunków elektrycznych w strefie tarcia przedstawiony jest to na rysunku 5.

Według Harvey'a i Wood'a generowanie ładunków ma miejsce w trakcie ocierania się cząsteczek wchodzących w skład płynów oraz podczas przemieszczania się gazów w cieczach [4].

Mechanizm występowania wyładowań elektrycznych w strefie tarcia nie jest do końca wyjaśniony. Wiadomym jest, że w wyniku tarcia, na powierzchniach ciał lub na granicach faz gromadzą się ładunki elektryczne. Powstają one na skutek przemieszczania się względem siebie materii $[4,10,11,14]$.

Jedną z hipotez dotyczącą wpływu zjawisk triboelektrycznych na opory tarcia przedstawiają Szczerek i Wiśniewski [23] twierdząc, że wyemitowane podczas tarcia elektrony są wychwytywane przez cząsteczki środka smarnego, znajdujące się najbliżej powierzchni tarcia, bądź powracają do jonów macierzystych. Jeżeli 
elektrony zwiążą się z cząstkami środka smarnego, wówczas tworzą się jony lub anionorodniki. Produkty reakcji elektronów $\mathrm{z}$ cząstkami mogą reagować $\mathrm{z}$ naładowaną powierzchnią tarcia, tworząc warstwę zabezpieczającą przed zużyciem i obniżającą tarcie [23]. Także różnego rodzaju dodatki przeciwtarciowe znajdujące się $\mathrm{w}$ substancji smarowej podlegają oddziaływaniu z powierzchnią metalową pod wpływem energii elektrycznej $[1,13]$. Zjawisko emisji cząsteczek nieobojętnych elektrycznie może zachodzić także pod wpływem reakcji chemicznych [14], jednakże jest to hipoteza dotychczas niepotwierdzona doświadczeniami.

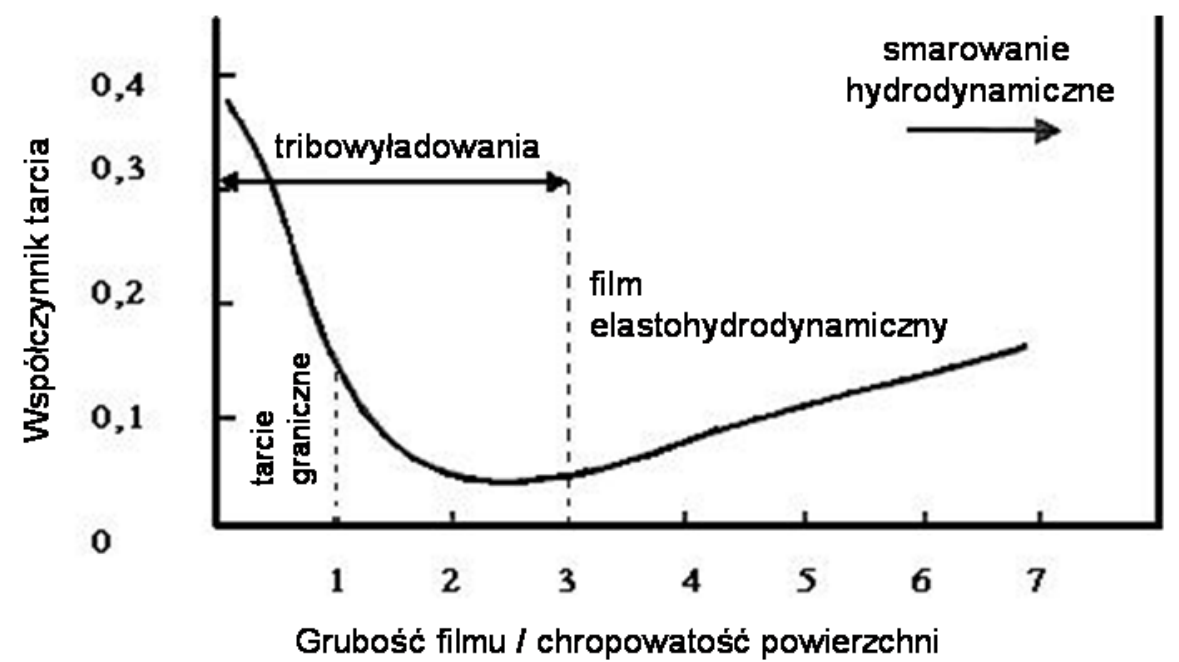

Rys. 5. Zakres występowania tribowyladowań elektrycznych [4]

Wiele publikacji $[5,11,16,18]$ wskazuje, że $\mathrm{w}$ eksperymentach $\mathrm{z}$ tarciem granicznym wraz ze wzrostem obciążenia następował wzrost grubości warstwy smarowej w strefie tarcia. Dlatego też można przypuszczać, że wzrost grubości filmu olejowego był skutkiem coraz większej intensywności tribowyładowań i tworzenia dodatkowej warstwy, ściśle związanej $\mathrm{z}$ występowaniem zjawisk triboelektrycznych.

Podejmując próby zbadania zjawiska emisji naładowanych cząsteczek podczas tarcia, przeprowadzono szereg doświadczeń tribologicznych, mierząc potencjał lub natężenie prądu w strefie tarcia $[3,4,10,18]$. Przedstawiony na rysunku 6 wynik takiego eksperymentu pokazuje ciągłą, lecz usystematyzowaną zmianę potencjału w strefie tarcia ze smarowaniem, przy stałych warunkach pracy $(\mathrm{p}, \mathrm{v}, \mathrm{T}=$ const).

Jak wynika z rysunku nr 6, amplituda zmian napięcia w strefie tarcia waha się w granicach $4 \mathrm{mV}$. Natomiast literatura przedstawia wartości napięć generowanych w węzłach tarcia dochodzące do ok. $1 \mathrm{~V}$. Wskazuje się również, że powstający 
potencjał pomiędzy powierzchniami trącymi smarowanymi olejem bazowym jest różny dla różnych skojarzeń $[3,4,8,10,14]$.

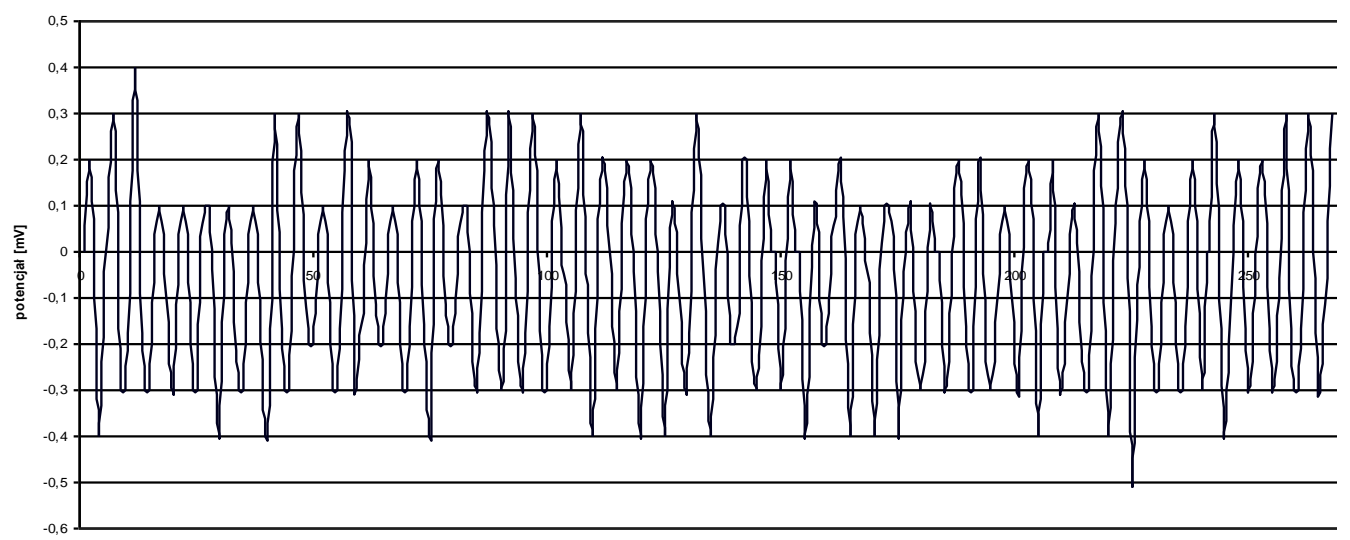

Rys.6. Przebieg zmian potencjatu w pomiędzy stalowymi powierzchniami tracymi w ustabilizowanych warunkach eksperymentu [11].

Mając na uwadze występowanie ładunków w strefie tarcia, co może wpływać na pomiar grubości filmu olejowego metodą elektryczną, autorzy przeprowadzili szereg eksperymentów mających na celu ustalenie korelacji rezystancji warstwy smarowej i jej grubości. Jedną z takich prób wykonanych na tribometrze TR-2 [9], przedstawiono na rys.7.

$\begin{array}{lllllll}h & R & F_{t} & p\end{array}$

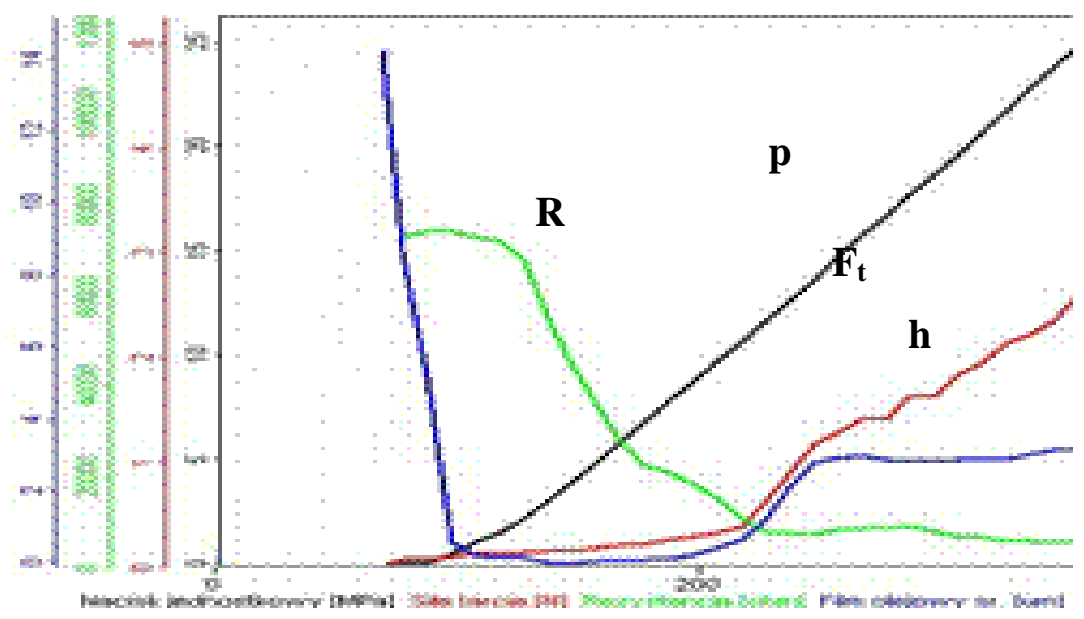

Rys.7. Przebieg zmian sity tarcia, rezystancji w strefie tarcia oraz grubości filmu olejowego w wyniku zmiany obciażenia. 
Powyższy wykres przedstawia kilka parametrów mierzonych w strefie tarcia, których przebieg uzależniony jest od zmiany obciążenia strefy tarcia $\boldsymbol{p}$. Uwagę zwrócić należy na wielkości $\boldsymbol{R}$ i $\boldsymbol{h}$ (rezystancję i grubość filmu olejowego), których zmiana powinna być proporcjonalna do rosnącego obciążenia. Jednak w przypadku tych trzech wielkości, nie widać bezpośredniej korelacji między nimi, a przynajmniej w całym zakresie realizowanego eksperymentu. $\mathrm{Na}$ odcinku, na którym rezystancja wyraźnie maleje, nie widać wyraźnych zmian grubości filmu smarowego, natomiast przy wciąż rosnącym obciążeniu, gwałtownie wzrasta wymiar warstwy olejowej bez jakiejkolwiek reakcji rezystancji w strefie tarcia.

Taka sytuacja skłania do głębszych refleksji na temat bezpośredniego łączenia rezystancji w strefie tarcia $\mathrm{z}$ grubością filmu olejowego.

\section{Podsumowanie}

Jak wynika z literatury, w wielu eksperymentach tribologicznych do oceny grubości filmu olejowego używane są metody elektryczne, a w szczególności rezystancyjna. Jednakże badania autorów oraz literatura dotycząca zjawisk triboelektrycznych pokazują, że jest to błędne podejście. Podczas tarcia hydrodynamicznego, gdzie intensywność tworzenia ładunków elektrycznych jest znikoma, można wskazywać na korelację rezystancji w strefie tarcia z grubością oleju znajdującego się pomiędzy powierzchniami tarcia. Natomiast podczas tarcia mieszanego lub granicznego, a nawet elastohydrodynamicznego, należy być ostrożnym przy bezpośrednim porównywaniu grubości warstwy olejowej z rezystancją. Powodem tego jest zmieniająca się przewodność filmu olejowego, w wyniku tworzenia się i akumulowania w oleju ładunków elektrycznych. Jak wynika z prawa Ohma, jakakolwiek zmiana napięcia elektrycznego lub natężenia prądu, będzie miała swoje odzwierciedlenie w wyniku otrzymanej rezystancji.

W związku z tym powinno się zwrócić większą uwagę na dobór odpowiedniej techniki badawczej do oceny grubości warstwy smarowej.

Dlatego też, jak stwierdzili Kulczycki i Wachal, aby z obserwacji strefy tarcia można było uzyskać stosunkowo wiarygodne informacje, należy stosować wiele złożonych metod badawczych [13].

\section{Literatura}

[1] Barwell F.T.: Łożyskowanie. WNT Warszawa 1984.

[2] Bowden F., Tabor D.: Wprowadzenie do trybologii. WNT Warszawa 1980.

[3] Cypko E., Kałdoński T.: Triboelectrical effect in frctional contacts. Solid State Phenomena vol.113, 2006.

[4] Harvey T., Wood R., Denuault G.: Investigation of electrostatic charging mechanisms in oil lubricated tribo-contact. Tribology International 35, 2002. 
[5] Hsu S.M., Gates R.S.: Boundary lubricating films: formation and lubrication mechanism. Tribology International 38, 2005.

[6] Irani K., Pekkari M., Angstrom H.-E.: Oil film thickness measurement in the middle main bearing of a six-cylinder supercharged 9 litre diesel engine using capacitive transducers. Wear 207, 1997.

[7] Jacobson B.: Thin film lubrication of real surfaces. Tribology International 33, 2000.

[8] Kaczyński R., Nachimowicz J.: Rezystancja kontaktu pary tracej w procesach przejściowych przy tarciu ślizgowym. Trybologia t. 3, 1994.

[9] Kajdas C., Krawczyk K., Nita J.: Metod and device for testing lubricating properties of lubricating means, Patent USA nr 4311036, 1981.

[10] Kałdoński T., Wachal A.: Powstawanie ładunków elektrycznych podczas tarcia metali o teflon. Trybologia t. 4-5, 1980.

[11] Krawczyk K., Firkowski A., Nowiński E.: Mierzenie zmian grubości filmu olejowego $w$ badaniach trybologicznych. Zeszyty Naukowe Instytutu Pojazdów PW nr 2/2010.

[12] Krupka I., Hartl M., Liska M.: Thin lubricating films behaviour at very high contact pressure.Tribology International Vol. 39, 2006.

[13] Kulczycki A., Wachal A.: Problemy energetyczne trwałości warstwy granicznej. Trybologia, t. 3, 1985.

[14] Nakayama K., Martin J.: Tribochemical reactions at and in the vicinity of a sliding contact. Wear 261, 2006.

[15] Peng-shun Z., Shu-guang L., Wen-jie Z.: A new measurement method of oil film thickness in the EHL condition: the $R$-C oscillation technique. Wear 148, 1991.

[16] Tamminen J., Sandstrom C.-E., Andersson P.: Influence of load on the tribological conditions in piston ring and cylinder liner contacts in a medium-speed diesel engine. Tribology International 39, 2006.

[17] Wachal A., Hebda M..: Trybologia, PWN 1980.

[18] Zhang Ch.: Research on thin film lubrication: state of the art.Tribology International vol. 38, 2005.

[19] Durak E., Kurbanoglu C., Kaleli H.:Measurement of friction force and effects of oil fortifier in engine journal bearings under dynamic loading conditions. Tribology International 36, 2003.

[20] Fuller D.D.: Teoria i praktyka smarowania. PWT Warszawa 1960.

[21] Dwyer-Joyce, R.S., Harper, P. and Drinkwater, B.W. A method for the measurement of hydrodynamic oil films using ultrasonic reflection. Tribology Letters, 2004, 17.

[22] Sherrington I.: A Review of the Development of Oil Film Thickness Measurement Technology and its Significance to the Understanding and Control of Lubrication in the Piston-Ring Packs of IC Engines. NordTrib Conference, 2010.

[23] Szczerek M., Wiśniewski M.: Tribologia, tribotechnika. PTT 2000. 
dr inż. Emil Nowiński - starszy specjalista badawczo - techniczny w Instytucie Technicznym Wojsk Lotniczych.

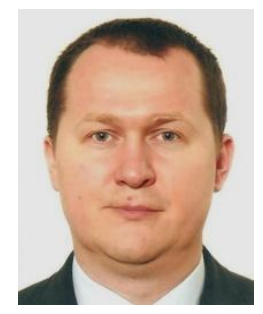

dr inż. Bolesław Giemza - główny specjalista badawczo - techniczny w Instytucie Technicznym Wojsk Lotniczych.

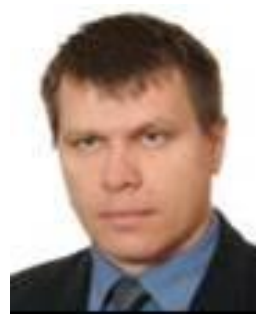

mgr inż. Marek Domański, absolwent Wojskowej Akademii Technicznej na kierunku Mechanika $i$ budowa maszyn, specjalista badawczo-techniczny w latach $2000-2005$ w WOBR St. MPS, a od 2005 w ITWL w Zaktadzie Materiatów Pędnych i Smarów, do 2013 r. petnit funkcje kierownika Pracowni Cieczy Roboczych 